Biological and Clinical Sciences Research Journal

ISSN: 2708-2261

www.bcsrj.com

DOI: https://doi.org/10.54112/bcsri.v2020i1.26

Biol. Clin. Sci. Res. J., Volume, 2020: 26

Original Research

\title{
GENETIC ASSOCIATION AMONG SEEDLING TRAITS OF ZEA MAYS UNDER MULTIPLE STRESSES OF SALTS, HEAVY METALS AND DROUGHT
}

\author{
MUQADAS S, *ALI Q, MALIK A \\ Institute of Molecular Biology and Biotechnology, The university of Lahore, Lahore, Pakistan \\ Corresponding author: saim1692@gamil.com
}

(Received, $10^{\text {th }}$ March 2020, Revised $7^{\text {th }}$ September 2020, Published $16^{\text {nd }}$ September 2020)

\begin{abstract}
Maize is highly sensitive for drought, heat, cold, salinity and heavy metals toxicity. The grain yield and quality of grains is highly affected due to abiotic environmental factors. For evaluating maize under drought as well as salts and heavy metals we have conducted an experiment in the greenhouse of IMBB (Institute of Molecular Biology and Biotechnology), University of the Lahore. Four maize genotypes were selected for our research work, viz., B-316, EV-1097Q, Raka-poshi and Sahiwal-2002. The seeds of selected maize genotypes were sown in 72 pots. Each of the pot was in triplicate for each of the maize genotype. The treatments of drought, salt and heavy metals were kept as following: Control, $50 \%$ irrigation water, $0.5 \mathrm{~m}$ Molar $\mathrm{NaCl}, 0.5 \mathrm{~m} \mathrm{Molar} \mathrm{ZnSO}_{4}, 0.5 \mathrm{~m} \mathrm{Molar} \mathrm{AlCl}_{3}$ and $0.5 \mathrm{~m} \mathrm{Molar} \mathrm{MgCl}_{2}$. It has been revealed from results the performance of maize genotypes was variable under different treatments of heavy metals, drought and salt stress environments. The treatments of $\mathrm{AlCl}_{3}$ and $\mathrm{NaCl}$ were found as the higher toxic treatments for most of the study traits of maize which may decrease the photosynthetic rate and accumulations of organic compounds in maize seedlings and may cause the death of seedlings. Significant and positive correlation was reported between shoot length other studied traits while the higher contribution for shoot length was reported for root length, leaf area and fresh root/shoot weight ratio. It was found from results that the Sahiwal-2002 performed better under all stress treatments for seedling traits as compared with B-316, Raka-poshi and EV-1097Q maize genotypes.
\end{abstract}

Keywords: Zea mays, salt, heavy metals, root length, shoot length, correlation, regression

\section{Introduction}

The Maize (Zea mays L.) as one of an important leading cash and food crops in the world occupied a significant role and position among all of the cultivated crop cultivars of cereal plants (Dixon et al., 2009). The cultivation or growing of maize is a symbolic of the green revolution which has played an important and pivotal role for fulfillment of nation food and nutrient requirements. Zea mays is an important member of family poaceae which is $95 \%$ cross pollinated plant (de Azevedo Neto et al., 2006; Fisher and Byerlee, 1990). It ranks at first among all of the worldwide food crop plants; in terms for its cultivated crop area which is $1097 \mathrm{~m}$ ha along with production of grain is $3.13 \mathrm{~m}$ tones however it has productivity potential up to $3264 \mathrm{~kg}$ ha-1 (Anonymous, 2018). It has ability to be grown as below as sea level up to $4000 \mathrm{~m}$ of altitude along with the areas where the rainfall is in the 250-300 $\mathrm{mm}$ range. It contributes higher calories up to $20 \%$ and also has higher protein contents as compared with other world's foods or diets even from all other food crop plants and species. The grain availability for maize is increasing from $79 \mathrm{~g}$ capita-1day- 1 up to as higher as $185 \mathrm{~g}$ capita-1day-1 however under the increasing population affects since 1960 (Ali et al., 2014a; Sheng et al., 2008). The maize is the $3 \mathrm{rd}$ most an important among cereal crops after rice and maize and was the key crop in green revolution. In Pakistan maize was grown on an area up to $1097 \mathrm{~m}$ ha along with grain production up to 3.13 million tones while the average grain productivity was $3.07 \mathrm{t} \mathrm{ha}^{-1}$ (Anonymous, 2018). The grain yield of maize has been highly affected due to abiotic environmental factors which included drought, salt, alkalinity, heat and cold stress. The world water demands and supply has been affected due to changing climate conditions (Karahara et al., 2004; Rohanipoor et al., 2013). The drought stress caused damage of cell membranes which lead towards the abnormality of cell growth and development in crop plants. The deficiencies of the nutrients in the soil also caused the decrease in the growth of maize. The long drought and heat stress conditions for maize growth in tropical and subtropical regions of the world have been highly affected which may lead towards the famine in those

[Citation: Muqadas, S., Ali, Q., Malik, A. (2020). Genetic association among seedling traits of Zea mays under multi stress of salt, heavy metals and drought. Biol. Clin. Sci. Res. J., 2020: 26. doi: https://doi.org/10.54112/bcsrj.v2020i1.26] 
maize growing area of world (Ali et al., 2015; Ali et al., 2016; Nadeem et al., 2006). Therefore, it is the need of hour to take another serious initiative to increase the plant productivity for major cash crops even with lower input to keep the sustainability of crop grain yield and production in maize. The crop productivity of maize is controlled through large number of factors among which mineral salt nutrition especially the nitrogen $(\mathrm{N})$, phosphorus $(\mathrm{P})$ and potassium $(\mathrm{K})$ are the most important nutrients (Shan et al., 2014; Shu and Liu, 2001). The abiotic environmental stress conditions caused damages on maize which highly affect to reduce grain yield and crop productivity of maize. The drought, heavy metals and salt stresses caused the damages in cell membrane, the production of organic toxic chemicals with the accumulation of highly reactive oxygen species (ROS) within the maize plant body parts (Aaliya et al., 2016; Rohanipoor et al., 2013; Zubair et al., 2016). Drought and salt stresses caused unrepairable damages in plant cell membranes, whoever the use of plant growth regulators may be helpful to keep plants healthy and withstand under any type of stress environmental conditions (de Azevedo Neto et al., 2006; Hütsch et al., 2014; Karahara et al., 2004).

\section{Materials and methods}

Maize is an important cereal crop which has been used by human from last thousands of years as grain crop. Maize is highly sensitive for drought, heat, cold, salinity and heavy metals toxicity. The grain yield and quality of grains is highly affected due to abiotic environmental factors. For evaluating maize for drought as well as salts and heavy metals we have conducted an experiment in the greenhouse of IMBB (Institute of Molecular Biology and Biotechnology), University of the Lahore. Four maize genotypes were selected for our research work, viz., Raka-poshi, B316, EV-1097Q and Sahiwal-2002. The seeds of selected maize genotypes were sown in 72 pots. Each of the pot was in triplicate for each of the maize genotype. The treatments of drought, salt and heavy metals were kept as following: $\mathrm{T}_{0}$ (Control), $\mathrm{T}_{1}(50 \%$ irrigation water $), \quad \mathrm{T}_{2} \quad\left(0.5 \mathrm{mMolar} \quad \mathrm{NaCl}, \quad \mathrm{T}_{3}\right.$ (0.5mMolar $\left.\mathrm{ZnSO}_{4}\right)$, T4 (0.5mMolar $\left.\mathrm{AlCl}_{3}\right)$ and $\mathrm{T}_{5}$ $\left(0.5 \mathrm{mMolar} \mathrm{MgCl}_{2}\right)$. The seeds were sown and after germination, the seedlings were given stress treatments after one week of germination. The drought treatment was carried out through the application of $200 \mathrm{ml}$ water to normal or control plants while $100 \mathrm{ml}$ to the plants under drought stress. The treatment of $\mathrm{NaCl}, \mathrm{ZnSO}_{4}, \mathrm{AlCl}_{3}$ and $\mathrm{MgCl}_{2}$ was applied through the irrigation of pots through adding $15 \mathrm{ml}$ to each pot. The seedling data was recorded for diverse morphological traits, as given below: leaf area, root/shoot dry weight ratio, roots per plant, root length, shoot length and root/shoot fresh weight ratio and statistical analysis was carried out through using SPSS 23.1 version.

\section{Results and discussions}

The results from table 1 revealed that there were significant differences among the maize genotypes under all applied treatments. The performance of all genotypes under control conditions was $100 \%$ in sense of survival under heavy metals and salt stress conditions. It was found results that the maize genotype Sahiwal-2002 showed higher performance under affects of all treatments as compared with other maize genotypes. The results from table 2 indicated that there was lower coefficient of variation for all studied traits which showed consistency of results, the average leaf area of maize genotypes under combined effects of all treatments was $6.342 \pm 0.0011 \mathrm{~cm}^{2}$, root per plant or seedling $6.945 \pm 0.0023$, dry root/shoot weight ratio $0.7203 \pm 0.0011$, fresh root/shoot weight ratio $0.9261 \pm 0.0002$, root length $23.013 \pm 1.0003 \mathrm{~cm}$ and shoot length $21.602 \pm 1.0264 \mathrm{~cm}$. The higher root and shoot lengths indicated that the seedlings showed tolerance for all applied treatments of salts and heavy metals. The selection of maize genotypes may be helpful to improve stress tolerance and enhance grain yield under stressful environmental conditions (Ali et al., 2011; Ashraf et al., 2020; Khalil et al., 2020).

Table 1. Survival percentage of maize genotypes under different multi stress conditions

\begin{tabular}{lllll}
\hline Treatments & B-316 & Raka-poshi & EV-1097Q & Sahiwal-2002 \\
\hline Control & 100 & 100 & 100 & 100 \\
$\mathbf{5 0 \%}$ irrigation water $\left(\mathbf{T}_{\mathbf{1}}\right)$ & 76.24 & 75.34 & 71.12 & 77.54 \\
$\mathbf{0 . 5 M o l a r ~} \mathbf{N a C l}\left(\mathbf{T}_{\mathbf{2}}\right)$ & 77.45 & 72.14 & 73.82 & 78.59 \\
$\mathbf{0 . 5 M o l a r} \mathbf{Z n S O}_{\mathbf{4}}\left(\mathbf{T}_{\mathbf{3}}\right)$ & 82.45 & 78.25 & 76.34 & 80.23 \\
$\mathbf{0 . 5 M o l a r} \mathbf{A l C l}_{\mathbf{3}}\left(\mathbf{T}_{\mathbf{4}}\right)$ & 81.34 & 80.21 & 72.24 & 82.13 \\
$\mathbf{0 . 5 M o l a r} \mathbf{M g C l}_{\mathbf{2}}\left(\mathbf{T}_{\mathbf{5}}\right)$ & 80.47 & 78.23 & 77.05 & 81.29 \\
\hline
\end{tabular}

Table 2. Genetic components for morphological traits of maize seedlings

\begin{tabular}{lllllll}
\multicolumn{7}{c}{ Table 2. Genetic components for morphological traits of maize seedlings } \\
\hline Source & LA & RPP & DRSWR & FRSWR & RL & SL \\
\hline Replication & 0.0001 & 0.0021 & 0.0002 & 0.0001 & 0.0065 & 0.0024 \\
Genotypes & $8 . .028^{*}$ & $2.0247^{*}$ & $0.00632^{*}$ & $0.0047 *$ & $59.2425^{*}$ & $43.261^{*}$ \\
Treatments & $7.947^{*}$ & $3.4148^{*}$ & $0.01213^{*}$ & $0.0161^{*}$ & $9.2621^{*}$ & $8.1023^{*}$
\end{tabular}

[Citation: Muqadas, S., Ali, Q., Malik, A. (2020). Genetic association among seedling traits of Zea mays under multi stress of salt, heavy metals and drought. Biol. Clin. Sci. Res. J., 2020: 26. doi: https://doi.org/10.54112/bcsrj.v2020i1.26] 


\begin{tabular}{lllllll} 
Genotypes $\times$ treatments & $19.302 *$ & $2.6024^{*}$ & $0.00418^{*}$ & $0.00133^{*}$ & $3.0231 *$ & $2.7425^{*}$ \\
Error & 0.0024 & 0.0032 & 0.00021 & 0.0002 & 0.0007 & 0.0302 \\
Grand Mean & 6.342 & 6.945 & 0.7203 & 0.9261 & 23.013 & 21.602 \\
Coefficient of variance $(\%)$ & 9.402 & 7.103 & 7.120 & 9.022 & 11.026 & 9.422 \\
Standard Error & 0.0011 & 0.0023 & 0.0011 & 0.0002 & 1.0003 & 1.0264 \\
Genetic advance & 23.024 & 17.189 & 13.142 & 21.821 & 23.232 & 23.032 \\
Broad sense heritability & 85.190 & 84.244 & 81.325 & 86.102 & 92.220 & 94.508 \\
\hline
\end{tabular}

$*=$ Significant at $5 \%$ probability level, DRSWR $=$ dry root/shoot weight ratio, FRSWR $=$ fresh root/shoot weight ratio, $\mathrm{RL}=$ root length, $\mathrm{SL}=$ shoot length, $\mathrm{RPP}=$ roots per plant, $\mathrm{LA}=$ leaf area

The figure 1 showed that the genotype EV-1097Q and Sahiwal-2002 showed better performance for leaf area as compared with B-316 and Raka-poshi under all different treatments of salts and heavy metals. The maize genotypes showed almost nearly similar number of root per seedling under all types of treatments (Figure 2). The root and shoot length of genotype EV-1097Q and Sahiwal-2002 was found higher as compared with B-316 and Raka-poshi under all different treatments of salts and heavy metals (Figures 3, 4). The higher fresh root/shoot weight ratio was found for B-316, and higher dry root/shoot weight ratio was found higher for Sahiwal2002 as compared with other genotypes under all of the applied treatments (Figures 5, 6 respectively). The higher root length, shoot length, fresh root/shoot weight ratio and dry root/shoot weight ratio indicated that the genotypes showed tolerance for salt and heavy metal stress conditions. The selection of maize genotypes for these traits may be useful for improving stress tolerance in maize genotypes to improve grain yield and production under varying environmental conditions (Masood et al., 2015; Mazhar et al., 2020; Saif-ul-malook et al., 2014).

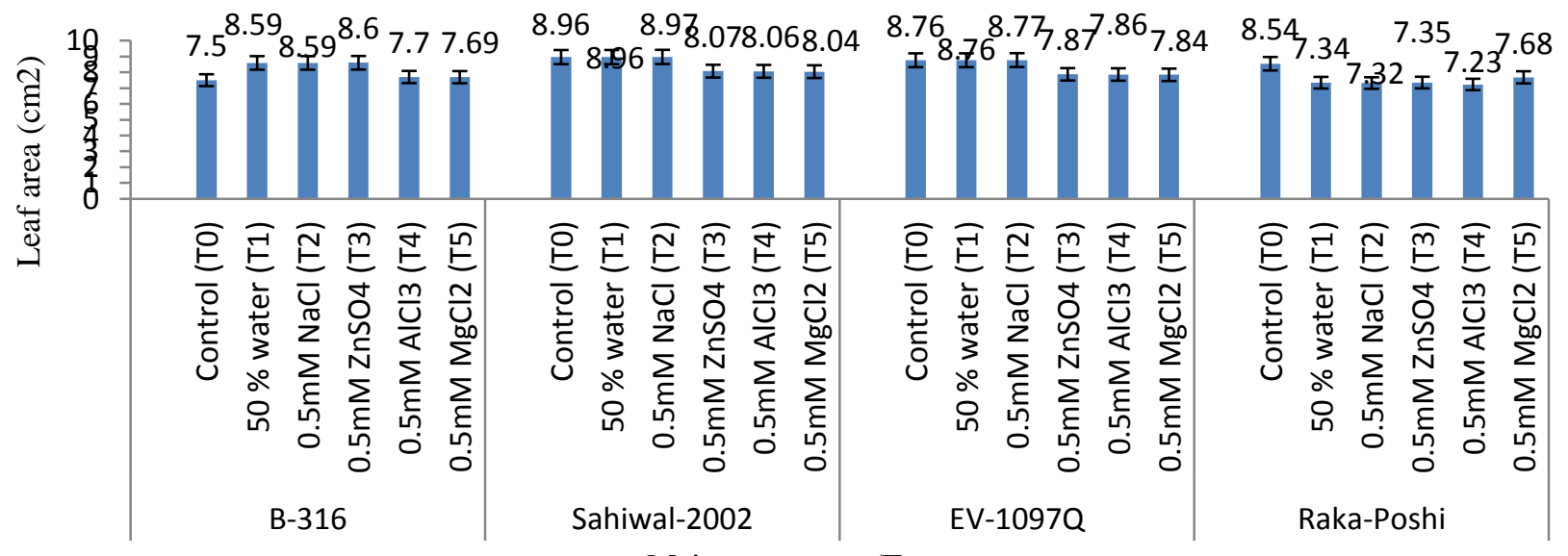

Maize genotypes/Treatments

Figure 1. Comparison of maize genotypes for leaf area under different treatments

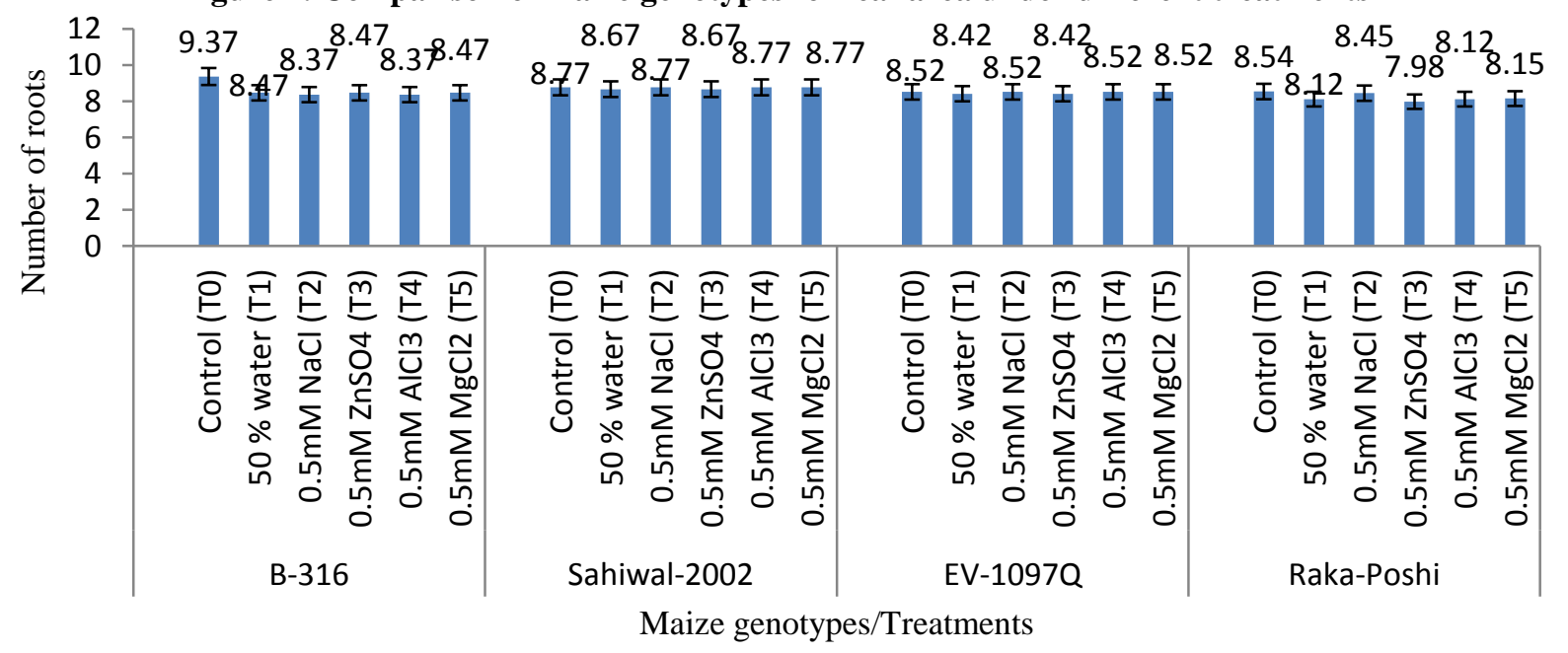

Figure 2. Comparison of maize genotypes for number of roots under different treatments

[Citation: Muqadas, S., Ali, Q., Malik, A. (2020). Genetic association among seedling traits of Zea mays under multi stress of salt, heavy metals and drought. Biol. Clin. Sci. Res. J., 2020: 26. doi: https://doi.org/10.54112/bcsrj.v2020i1.26] 


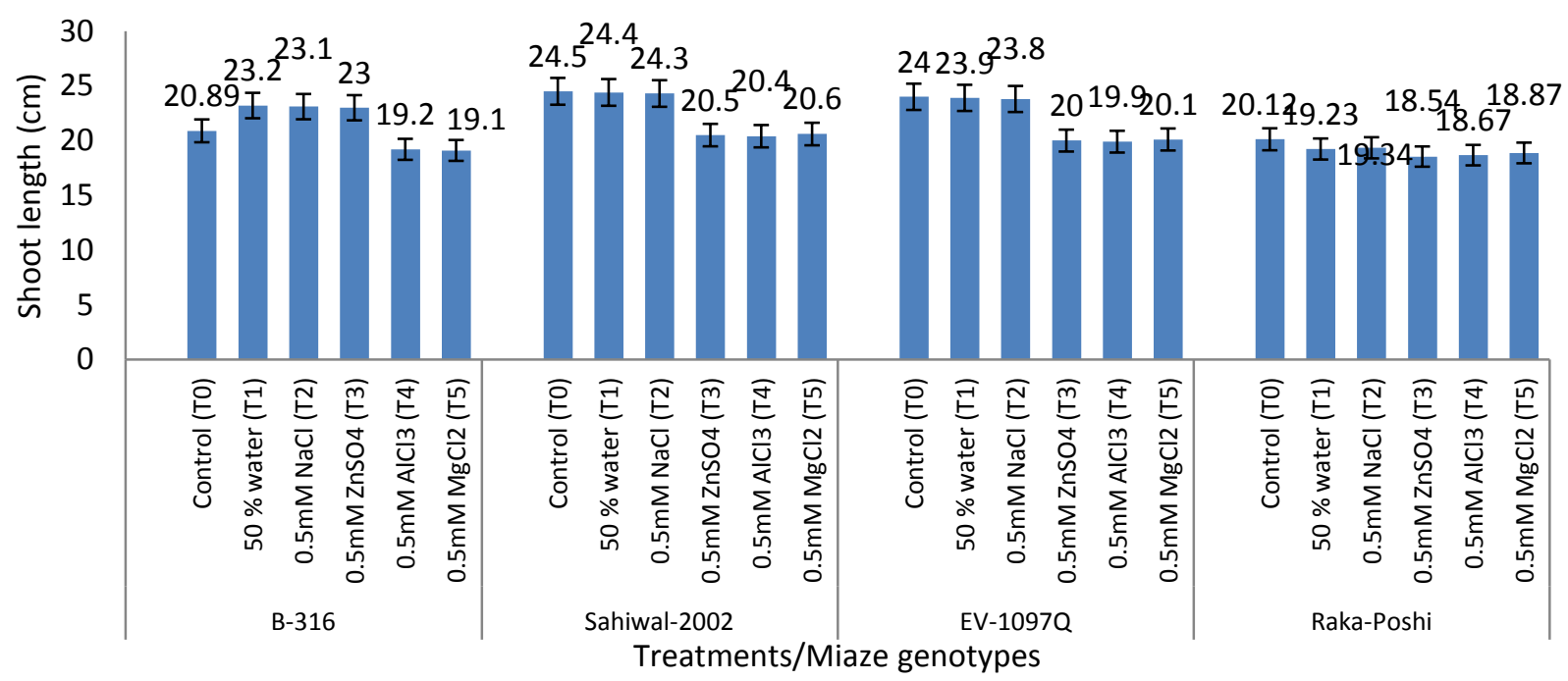

Figure 3. Comparison of maize genotypes for shoot length under different treatments

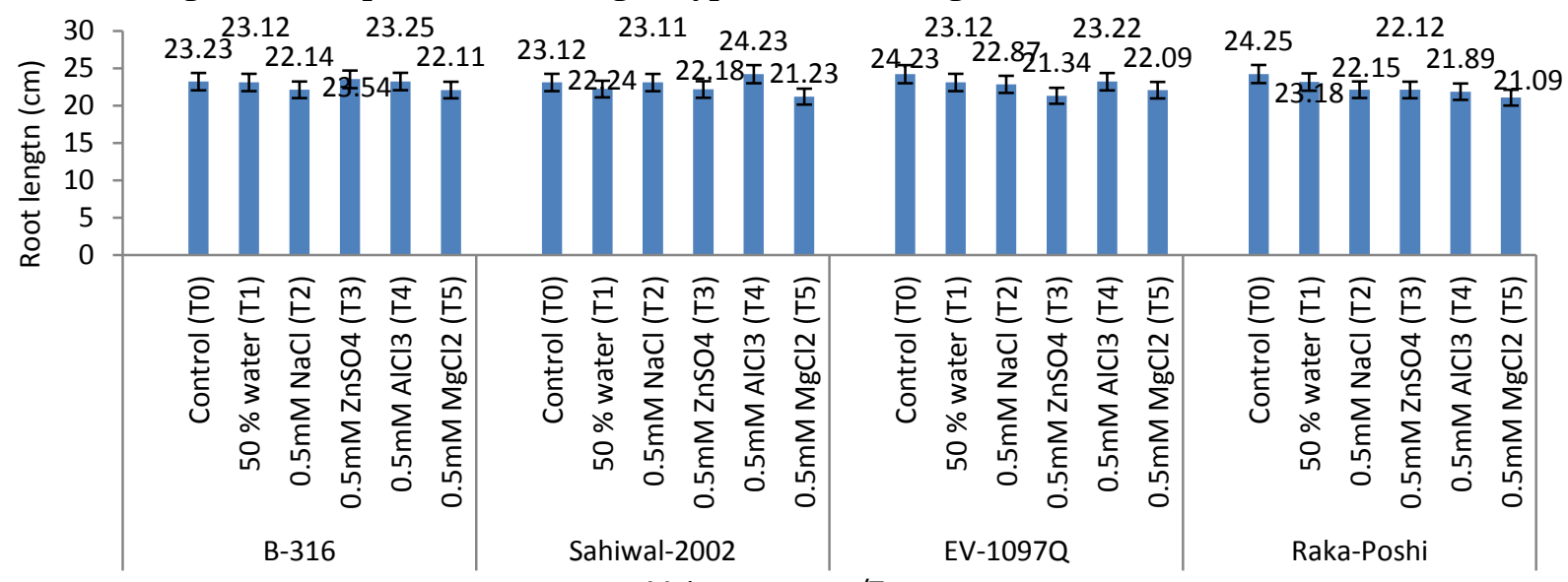

Maize genotypes/Treatments

Figure 4. Comparison of maize genotypes for root length under different treatments

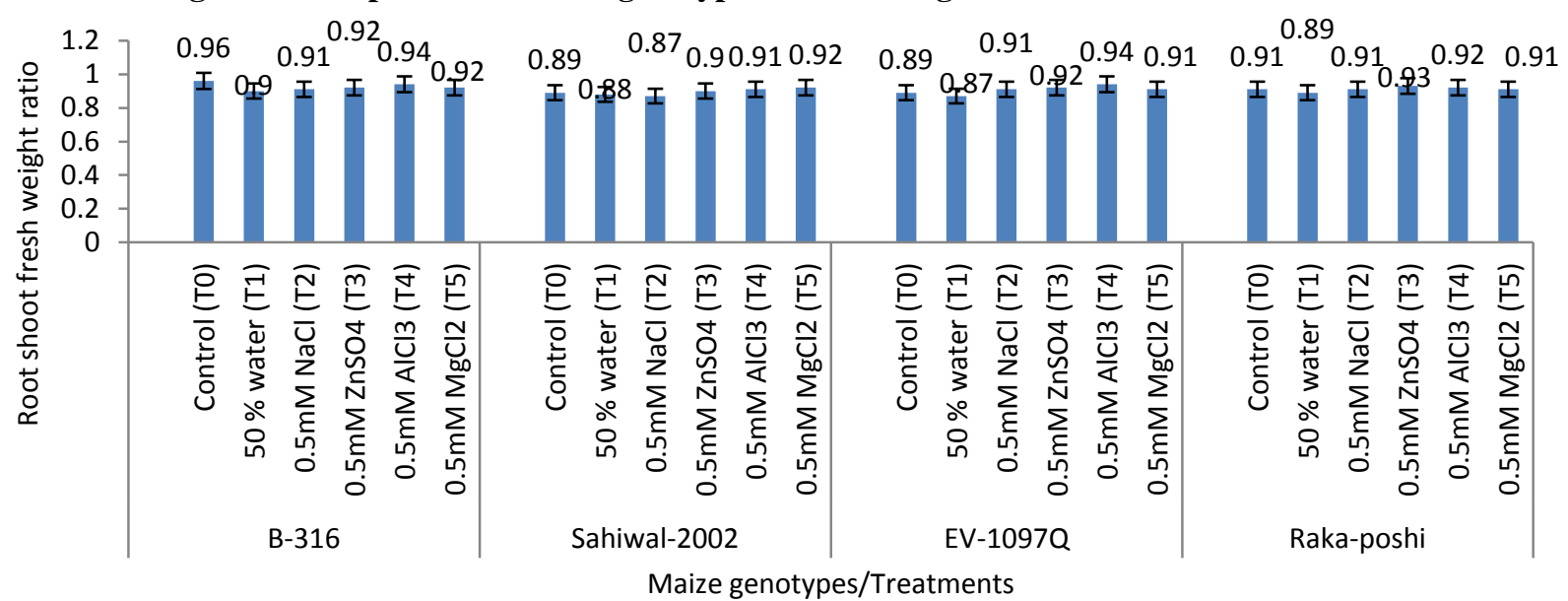

Figure 5. Comparison of maize genotypes for fresh root/shoot weight ratio under different treatments

[Citation: Muqadas, S., Ali, Q., Malik, A. (2020). Genetic association among seedling traits of Zea mays under multi stress of salt, heavy metals and drought. Biol. Clin. Sci. Res. J., 2020: 26. doi: https://doi.org/10.54112/bcsrj.v2020i1.26] 


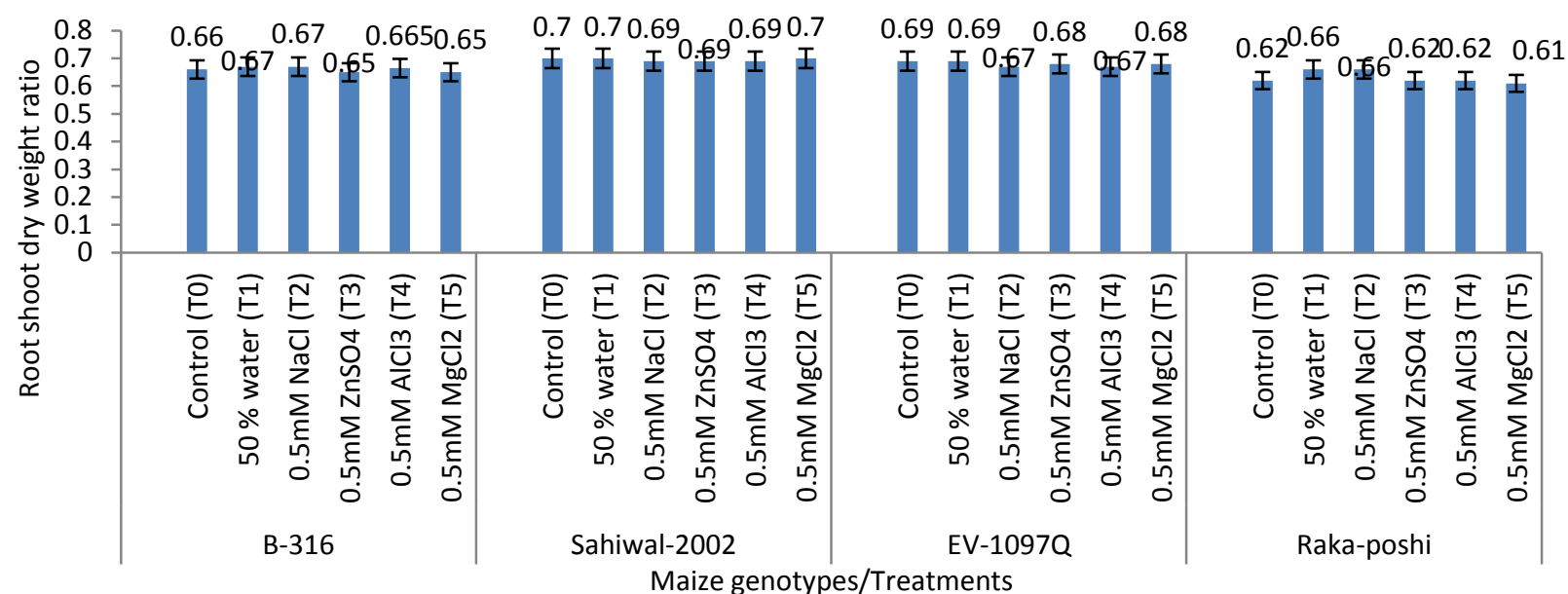

Figure 6. Comparison of maize genotypes for dry root/shoot weight ratio under different treatment

The results from table 3 indicated correlation among studied traits, there was significant and positive correlation among root length, shoot length, dry root/shoot weight ratio, fresh root/shoot weight, roots per plant and leaf area. The significant correlation between rot and shoot length indicated that the selection on the basis of these traits may be helpful to induce stress tolerance in maize genotypes. From regression analysis it was found that root length was higher contributor towards shoot length was reported as 7.6031 followed by leaf area (4.4012), fresh root/shoot weight ratio (4.3022) while negative contribution was found for root per plant (-1.0172) and dry root/shoot weight ratio (-3.020). The higher and positive contribution of root length and leaf area indicated that there was higher photosynthetic rate under stress conditions and absorption of inorganic mineral salts and water from soil which leads to improve plant growth and development (Abbas et al., 2016; Ali et al., 2017; Ali et al., 2014b; Boomsma et al., 2009; Saif-ul-malook et al., 2014; Tahir et al., 2020). The predicted regression equation was $\mathrm{Y}=$ $1.217+7.6031(\mathrm{RL})+4.4012(\mathrm{LA})-3.020(\mathrm{DRSWR})$ +4.3022 (FRSWR) - 1.0172(RPP)

Table 3. Correlation among morphological traits of maize

\begin{tabular}{llllll}
\hline Traits & LA & RPP & DRSWR & FRSWR & RL \\
\hline RPP & $0.4234^{*}$ & & & & \\
DRSWR & -0.0092 & 0.1294 & & & \\
FRSWR & 0.1923 & 0.2120 & $0.5012^{*}$ & & \\
RL & $0.5674^{*}$ & $0.2925^{*}$ & $-0.6624^{*}$ & -0.1002 & \\
SL & $0.8421^{*}$ & $0.6304^{*}$ & $0.8724^{*}$ & $0.9101^{*}$ & $0.7972^{*}$ \\
\hline
\end{tabular}

$*=$ Significant at $5 \%$ probability level, DRSWR $=$ dry root/shoot weight ratio, FRSWR $=$ fresh root/shoot weight ratio, $\mathrm{RL}=$ root length, $\mathrm{SL}=$ shoot length, $\mathrm{RPP}=$ roots per plant, $\mathrm{LA}=$ leaf area

Table 4. Regression analysis for shoot length among morphological traits of maize

\begin{tabular}{lllllll}
\hline Traits & Coefficients & $\begin{array}{l}\text { Standard } \\
\text { Error }\end{array}$ & t Stat & Partial R & $\begin{array}{l}\text { Lower } \\
\mathbf{9 5 \%}\end{array}$ & $\begin{array}{l}\text { Upper } \\
\mathbf{9 5 \%}\end{array}$ \\
\hline RL & 7.6031 & 0.001 & -0.0132 & 0.6712 & 0.0313 & 0.0412 \\
LA & 4.4012 & 0.1202 & 0.0028 & 0.4602 & 0.0012 & 0.2901 \\
DRSWR & -3.020 & 0.0029 & -1.0018 & 0.1502 & -0.0342 & 0.4205 \\
FRSWR & 4.3022 & 0.0167 & 4.0128 & 0.0421 & -1.1082 & 1.3202 \\
RPP & -1.0172 & 0.0108 & 0.2012 & 0.0322 & -0.0245 & 0.0116 \\
\hline
\end{tabular}

$\mathrm{Y}=1.217$, Multiple $\mathrm{R}^{2}=0.8534, \mathrm{R}^{2}=0.6823$, Adjusted $\mathrm{R}^{2}=0.6424$, Standard Error $=0.0231 \mathrm{DRSWR}=\mathrm{dry}$ root/shoot weight ratio, FRSWR = fresh root/shoot weight ratio, RL= root length, $\mathrm{SL}=$ shoot length, $\mathrm{RPP}=$ roots per plant, LA = leaf area

\section{Conflict of interest}

The authors have declared absence of any type of conflict of interest.

\section{References}

Aaliya, K., Qamar, Z., Ahmad, N. I., Ali, Q., Munim, F. A., and Husnain, T. (2016). Transformation, evaluation of gtgene and multivariate genetic analysis for morpho-physiological and yield attributing traits in Zea mays. Genetika 48, 423-433.

[Citation: Muqadas, S., Ali, Q., Malik, A. (2020). Genetic association among seedling traits of Zea mays under multi stress of salt, heavy metals and drought. Biol. Clin. Sci. Res. J., 2020: 26. doi: https://doi.org/10.54112/bcsrj.v2020i1.26] 
Abbas, H. G., Mahmood, A., and Ali, Q. (2016). Zero tillage: a potential technology to improve cotton yield. Genetika 48, 761-776.

Ali, F., Ahsan, M., Ali, Q., and Kanwal, N. (2017). Phenotypic stability of Zea mays grain yield and its attributing traits under drought stress. Frontiers in plant science 8, 1397.

Ali, F., Kanwal, N., Ahsan, M., Ali, Q., Bibi, I., and Niazi, N. K. (2015). Multivariate analysis of grain yield and its attributing traits in different maize hybrids grown under heat and drought stress. Scientifica 2015.

Ali, Q., Ahsan, M., Kanwal, N., Ali, F., Ali, A., Ahmed, W., Ishfaq, M., and Saleem, M. (2016). Screening for drought tolerance: comparison of maize hybrids under water deficit condition. Advancements in Life Sciences 3, 51-58.

Ali, Q., Ahsan, M., Tahir, M. H. N., and Basra, S. M. A. (2014a). Gene action and correlation studies for various grain and its contributing traits in maize (Zea Mays L). Bothalia 44, 8091.

Ali, Q., Ali, A., Ahsan, M., Nasir, I. A., Abbas, H. G., and Ashraf, M. A. (2014b). Linex Tester analysis for morpho-physiological traits of Zea mays L seedlings. Advancements in Life sciences 1, 242-253.

Ali, Q., Hammad, M., Tahir, N., Ahsan, M., Basra, S. M. A., Farooq, J., and Elahi, M. (2011). Correlation and path coefficient studies in maize (Zea mays L.) genotypes under $40 \%$ soil moisture contents. African Journal of Bacteriology Research 3, 77-82.

Anonymous (2018). "Economic Survey of Pakistan. Govt. of Pakistan, Finance and Economic Affairs Division, Islamabad.."

Ashraf, A., Rashid, M., Ali, Q., and Malik, A. (2020). Genetic Advances and Heritability Analysis for Seedling Growth Traits in Zea mays under Heavy Metal Stress. Genetics and Molecular Research 19.

Boomsma, C. R., Santini, J. B., Tollenaar, M., and Vyn, T. J. (2009). Maize morphophysiological responses to intense crowding and low nitrogen availability: An analysis and review. Agronomy Journal 101, 1426-1452.

de Azevedo Neto, A. D., Prisco, J. T., Enéas-Filho, J., de Abreu, C. E. B., and Gomes-Filho, E. (2006). Effect of salt stress on antioxidative enzymes and lipid peroxidation in leaves and roots of salt-tolerant and salt-sensitive maize genotypes. Environmental and Experimental Botany 56, 87-94.
Dixon, J., Braun, H.-J., Kosina, P., and Crouch, J. H. (2009). "Wheat facts and futures 2009," Cimmyt.

Fisher, R., and Byerlee, D. (1990). Trends of wheat production in the warmer areas: major issues and economic considerations. In "3. International Conference on Wheat for the Nontraditional Warm Areas, Foz do Iguacu (Brazil), 29 Jul-3 Aug 1990". CIMMYT.

Hütsch, B. W., Saqib, M., Osthushenrich, T., and Schubert, S. (2014). Invertase activity limits grain yield of maize under salt stress. Journal of plant nutrition and soil science 177, 278286.

Karahara, I., Ikeda, A., Kondo, T., and Uetake, Y. (2004). Development of the Casparian strip in primary roots of maize under salt stress. Planta 219, 41-47.

Khalil, M., Rashid, M., Ali, Q., and Malik, A. (2020). Genetic Evaluation for Effects of Salt and Drought Stress on Growth Traits of Zea mays Seedlings. Genetics and Molecular Research 19.

Masood, S. A., Jabeen, S., Anum, M., Naseem, Z., Jamshaid, A., and Ali, Q. (2015). Genetic Association of transcriptional factors (OsAP2 gene family) to incorporate drought tolerance in rice. Life Science Journal 12, 71-76.

Mazhar, T., Ali, Q., and Malik, M. S. R. A. (2020). Effects of salt and drought stress on growth traits of Zea mays seedlings. Life Science Journal 17.

Nadeem, S. M., Zahir, Z. A., Naveed, M., Arshad, M., and Shahzad, S. (2006). Variation in growth and ion uptake of maize due to inoculation with plant growth promoting rhizobacteria under salt stress. Soil Environ 25, 78-84.

Rohanipoor, A., Norouzi, M., Moezzi, A., and Hassibi, P. (2013). Effect of silicon on some physiological properties of maize (Zea mays) under salt stress. Journal of Biodiversity and Environmental Sciences 7, 71-79.

Saif-ul-malook, M. A., Ali, Q., and Mumtaz, A. (2014). Inheritance of yield related traits in maize (Zea mays) under normal and drought conditions. Nat Sci 12, 36-49.

Shan, C., Liu, H., Zhao, L., and Wang, X. (2014). Effects of exogenous hydrogen sulfide on the redox states of ascorbate and glutathione in maize leaves under salt stress. Biologia plantarum 58, 169-173.

Sheng, M., Tang, M., Chen, H., Yang, B., Zhang, F., and Huang, Y. (2008). Influence of arbuscular mycorrhizae on photosynthesis and water

[Citation: Muqadas, S., Ali, Q., Malik, A. (2020). Genetic association among seedling traits of Zea mays under multi stress of salt, heavy metals and drought. Biol. Clin. Sci. Res. J., 2020: 26. doi: https://doi.org/10.54112/bcsrj.v2020i1.26] 
status of maize plants under salt stress. Mycorrhiza 18, 287-296.

Shu, L., and Liu, Y. (2001). Effects of silicon on growth of maize seedlings under salt stress. Agro-Environmental Protection 20, 38-40.

Tahir, M., Rashid, M., Ali, Q., and Malik, A. (2020). Evaluation of Genetic Variability in Wheat and Maize under Heavy Metal and Drought Stress. Genetics and Molecular Research 19.

Zubair, M., Shakir, M., Ali, Q., Rani, N., Fatima, N., Farooq, S., Shafiq, S., Kanwal, N., Ali, F., and Nasir, I. A. (2016). Rhizobacteria and phytoremediation of heavy metals. Environmental Technology Reviews 5, 112119.

\section{(c) (7) (5)}

Open Access This article is licensed under a Creative Commons Attribution 4.0 International License, which permits use, sharing, adaptation, distribution and reproduction in any medium or format, as long as you give appropriate credit to the original author(s) and the source, provide a link to the Creative Commons licence, and indicate if changes were made. The images or other third party material in this article are included in the article's Creative Commons licence, unless indicated otherwise in a credit line to the material. If material is not included in the article's Creative Commons licence and your intended use is not permitted by statutory regulation or exceeds the permitted use, you will need to obtain permission directly from the copyright holder. To view a copy of this licence, visit http://creativecommons.org/licen ses/by/4.0/.

(C) The Author(s) 2021

[Citation: Muqadas, S., Ali, Q., Malik, A. (2020). Genetic association among seedling traits of Zea mays under multi stress of salt, heavy metals and drought. Biol. Clin. Sci. Res. J., 2020: 26. doi: https://doi.org/10.54112/bcsrj.v2020i1.26] 